\title{
Long-term effects of fishing on physiological performance of the Manila clam (Ruditapes philippinarum) in the Lagoon of Venice
}

\author{
VANESSA MOSCHINO $^{1,2}$, LUIS CHICHARO $^{3}$ and MARIA GABRIELLA MARIN ${ }^{1}$ \\ ${ }^{1}$ Department of Biology, University of Padova, Via Ugo Bassi 58/B, 35131 Padova, Italy. E-mail: mgmar@ bio.unipd.it \\ ${ }_{2}^{2}$ ISMAR-CNR, Castello 1364/A 30122 Venezia, Italy. \\ ${ }^{3}$ Centre of Marine Sciences, CCMAR, University of Algarve, Campus de Gambelas, 8005-139 Faro, Portugal.
}

SUMMARY: The Manila clam (Ruditapes philippinarum) is an important economic resource for fisheries in the Lagoon of Venice, where this species is fished and farmed. With the aim of evaluating possible fishing-induced long-term effects undergone by clam populations subjected to fishing efforts, physiological biomarkers were measured at organism level (clearance and respiration rates, scope for growth and survival-in-air test). Clams were collected on a seasonal basis from sites characterized by various fishing management practices: a free fishing area at S. Angelo and an area licensed for clam farming at Chioggia, where a non-fishing sub-area was established. $R$. philippinarum collected at S. Angelo generally showed reduced filtering activity and higher oxygen consumption, revealing general worsening in clam well-being in comparison with individuals from both Chioggia areas. This condition, resulting in lower standardized scope for growth values, may be explained by both environmental and fishing effort differences. Comparing Chioggia samples, better physiological performances were exhibited by clams from the non-fishing area, though no significant differences were observed. In winter, the survival-in-air test revealed the detrimental effects of fishing on clams, whereas in the other seasons this response generally seemed to be mostly related to other exogenous and endogenous factors. Although differences among sites and seasons were always statistically significant, all physiological parameters indicate the great tolerance of $R$. philippinarum to changing environmental conditions.

Keywords: Ruditapes philippinarum, Lagoon of Venice, physiological responses, scope for growth, fishing impact, clam culture.

RESUMEN: EFECTOS A LARGO PLAZO DE LA PESCA EN EL RENDIMIENTO FISIOLÓGICO DE LA ALMEJA DE MANILA RUDITAPES PHILIPPINARUM EN LA LAGUNA DE VENECIA. - La almeja Ruditapes philippinarum representa un recurso económico importante para la pesca en la laguna de Venecia, donde esta especie se pesca y se cría. Para evaluar los posibles efectos a largo plazo sufridos por las poblaciones de almejas expuestas al esfuerzo de pesca, se han medido algunos marcadores fisiológicos a nivel de los organismos (tasa de aclarado, tasa de respiración, energía disponible para el crecimiento y supervivencia en pruebas fuera del agua). Las almejas se recolectaron estacionalmente en lugares caracterizados por varias prácticas de gestión de la pesca: un área de pesca libre en S.Angelo y un área autorizada para la crianza de almejas en Chioggia, donde se puso una sub-área no usada para la pesca. $R$. philippinarum recogida en S. Angelo generalmente ha mostrado una actividad de filtración reducida y una consumición de oxígeno más alta, entonces hubo un empeoramiento en el bienestar de las almejas en comparación con los individuos de ambas área de Chioggia. Esta condición, que resulta en valores más bajos en la energía disponible para el crecimiento estandarizada, puede ser explicado por las diferencias ambientales y de la pesca. Confrontando las muestras de Chioggia, las almejas del área no usada para la pesca mostraron un rendimiento fisiológico mejor, aunque no hubo diferencias significativas. En invierno la supervivencia fuera del agua reveló los efectos perjudiciales de la pesca en las almejas, mientras que en otras temporadas esta respuesta generalmente parecía más relacionada con otros factores exógenos y endógenos. Aunque las diferencias entre lugares y estaciones han sido siempre significativas desde un punto de vista estadístico, todos los parámetros indican la gran tolerancia de $R$. philippinarum al cambio de las condiciones ambientales.

Palabras clave: Ruditapes philippinarum, laguna de Venecia, respuesta fisiológica, energía disponible para el crecimiento, impacto de la pesca, crianza de almejas. 


\section{INTRODUCTION}

Commercial bottom fishing gear may cause widespread physical disturbance in sediments affecting benthic communities, removing both target and nontarget species, and altering habitats. Many studies have been carried out to assess the impact of fishing gear used for harvesting molluscs, particularly dredges, on bycatch species and benthic communities (e.g.-Pranovi et al., 2001; Hauton et al., 2003; Gaspar et al., 2009; Leitão et al., 2009). The few studies available on the effects of commercial fishing on target species focus mainly on the qualitative/quantitative assessment of the discarded clams and on the selectivity of the fishing gear (Gaspar et al., 2003; Morello et al., 2005; Kraan et al., 2007). The effects of dredging on habitats include changes in the physical structure and chemistry of the environment, and sediment suspension and its redistribution (see Gaspar and Chicharo 2007, for a review). The alteration of sediment features may influence the colonization and presence of benthic species, including target ones, leading to long-term changes in community structure (Pranovi and Giovanardi, 1994; Pranovi et al., 1998). Until now, most research has focused on short-term changes, and less attention has been given to long-term effects of fishing impact (Gaspar and Chicharo, 2007). Indeed, medium- to long-term changes are more difficult to evaluate, as studies are usually based on comparisons between fished and unfished grounds. This may lead to inconsistent or confusing results, as unfished areas generally differ physically from fished ones (Gaspar and Chicharo, 2007).

Physiological biomarkers are generally employed to evaluate the well-being of marine and estuarine organisms subject to natural and/or anthropogenic stressors. Among these, clearance and respiration rate, scope for growth and the survival-in-air test are known to be responsive to previously experienced stress conditions, mostly related to pollution (Eertman et al., 1993; Widdows et al., 1997; Wepener et al., 2008), and to be useful for comparing various bivalve populations (Labarta et al., 1997; Marin et al., 2001). Scope for growth (SFG) estimates the amount of energy available for growth and reproduction by measuring the organism's energy budget, and is defined as the difference between energy absorbed from food and energy lost via excretion and metabolism (Smaal and Widdows, 1994). Survival-in-air exploits the natural ability of bivalves to survive periods of aerial exposure (Eertman et al., 1993). Some general stress indices, including physiological biomarkers, have recently been successfully applied to highlight stress induced by fishing on target species in both laboratory experiments and field surveys, but they generally consider only short-term effects on bivalve populations (Chicharo et al., 2003; Da Ros et al., 2003; Marin et al., 2005; Chicharo and Chicharo, 2008; Moschino et al., 2008).

The Manila clam (Ruditapes philippinarum) is an allochthonous species which was introduced into the

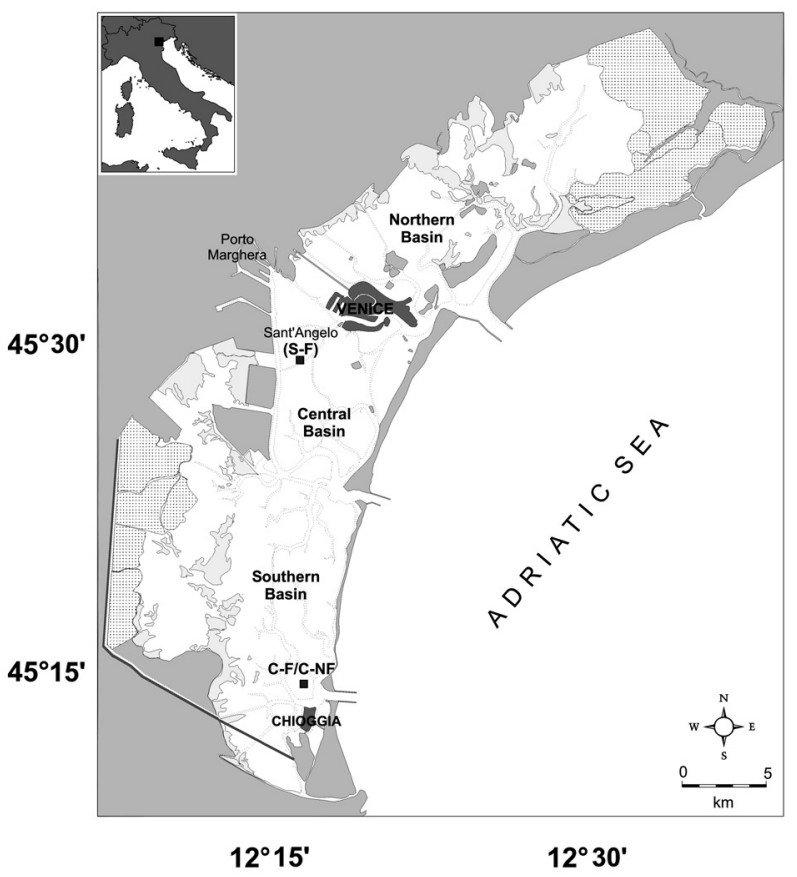

FIG. 1. - The study areas located in the Lagoon of Venice.

Lagoon of Venice for aquaculture purposes in the early 1980 s, and soon became widespread in the entire lagoon. Since then, fishing of $R$. philippinarum has become very profitable in the Lagoon, due to the successful recruitment and high productivity of this species. Farming and fishing are important economic resources: 95\% of total Italian production comes from the northern Adriatic (Pellizzato and Da Ros, 2005). This high productivity has led to intense and destructive fishing pressure, which is increased by illegal activities such as using unauthorized gear and/or fishing in banned areas, which are widespread throughout the Lagoon. At present, clams are mainly caught using various types of mechanical dredge, which may affect the physiological condition of the organisms.

The aim of the present study was to evaluate the long-term effects of fishing on the physiological performance of the target species $R$. philippinarum, collected from various fishing grounds inside the Lagoon of Venice.

\section{MATERIALS AND METHODS}

\section{Clam sampling}

Ruditapes philippinarum specimens were collected from two clam grounds, respectively in the central (S. Angelo) and in the southern basin (Chioggia) of the Lagoon of Venice (Fig. 1). S. Angelo (S-F) is a free fishing area near the industrial zone of Porto Marghera, in which uncontrolled and illegal fishing is carried out using both manual rakes and unauthorized dredges (mechanical, hydraulic and vibrating gear), despite the ban due to high levels of pollution (Bellucci et al., 2002; 
TABLE 1. - Temperature and salinity values recorded at $\mathrm{S}$. Angelo (S-F) and Chioggia (C-F, C-NF) during sampling.

\begin{tabular}{lcccc}
\hline & \multicolumn{2}{c}{ S-F } & \multicolumn{2}{c}{$\mathrm{C}-\mathrm{F} / \mathrm{C}-\mathrm{NF}$} \\
& ${ }^{\circ} \mathrm{C}$ & $\mathrm{psu}$ & ${ }^{\circ} \mathrm{C}$ & $\mathrm{psu}$ \\
\hline September & 21.4 & 34 & 22.0 & 34 \\
January & 5.0 & 33 & 3.0 & 30 \\
April & 16.1 & 28 & 16.2 & 32 \\
July & 27.0 & 31 & 24.3 & 33 \\
\hline
\end{tabular}

Apitz et al., 2007). At Chioggia, samples were collected from a clam farm (C-F) - a lagoon area licensed to fishermen by local authorities - close to the mouth of the lagoon and particularly affected by tidal currents, which increase the sandy component in sediments. At this farm, fishermen harvested bivalves almost daily with hydraulic dredges. Two months before the first experimental survey, a non-fishing control sub-area (C-NF) was established within this fishing area.

Approximately 200 clams $(30 \pm 2 \mathrm{~mm}$ in length) were seasonally sampled in September 2000, January, April and July 2001 in all areas by manual raking. During sampling, the temperature and salinity of sea water were measured (Table 1) and water samples were collected to determine particulate organic matter (POM) content. After sampling, clams were kept refrigerated, transferred to the laboratory within two hours, and immediately processed.

\section{Physiological measurements}

Clearance rate, respiration rate and scope for growth (SFG) were determined on 12-16 individual clams per site, following the method of Widdows (1985). The animals were acclimatized for $30 \mathrm{~min}$ in filtered seawater (Whatman GFC, particle retention > $1.2 \mu \mathrm{m}$ ) before measurements, which were performed at the same temperature and salinity measured in the seawater during seasonal sampling.

The clearance rate (CR), expressed as volume of water cleared of suspended particles per unit of time, was determined by a static approach: individual animals were placed in a glass beaker containing 2.51 of $0.45-\mu \mathrm{m}$ filtered aerated seawater and Isochrysis galbana (30000 cells $\mathrm{ml}^{-1}$ ) was added. One beaker without clams was used as a control. The microalgae concentration was measured on 20-ml aliquots collected from each beaker every $30 \mathrm{~min}$ over a period of $1.5 \mathrm{~h}$ by a Coulter Counter (Model Z2). For each clam, the CR value was defined on the basis of a 1-h period (two consecutive time increments).

The rate of oxygen consumption was monitored for $45 \mathrm{~min}$ in closed plexiglas chambers ( $800 \mathrm{ml}$ capacity) with a perforated plate supporting the clam and a magnetic stirrer bar underneath. Each respiration chamber was filled with air-saturated filtered seawater, placed on the magnetic stirrer and provided with a calibrated oxygen electrode (Strathkelvin 1302), connected to a multichannel oxygen system (Strathkelvin 928 Interface). A respirometer without animals was used as a control.
Food absorption efficiency (AE) was estimated according to the method of Conover (1966): the proportion of organic matter in the seston was compared with that in faeces. POM was evaluated by filtering seawater from field sampling through Whatman GFC fibre filters. Organic matter in faeces was determined on four subsamples from about 50 clams each: clams were placed in tanks containing filtered seawater for $4 \mathrm{~h}$ and faeces were then collected on Whatman GFC fibre filters. Filters with seston and faeces were dried for $48 \mathrm{~h}$ in an oven at $60^{\circ} \mathrm{C}$, weighed, ashed at $450^{\circ} \mathrm{C}$ for $6 \mathrm{~h}$ and then re-weighed.

Physiological measurements were weight-corrected to a 'standard' body mass of $0.2 \mathrm{~g}$ dry weight, corresponding to the mean dry weight of the clams analyzed. The allometric coefficients were calculated in previous studies for R. philippinarum from the same area. Briefly, the influence of body size on clearance and respiration rates was studied by a series of measurements on clams of differing size; when clearance and respiration measurements were completed, the dry weight of each individual was determined after $48 \mathrm{~h}$ in an oven at $60^{\circ} \mathrm{C}$, constant weight being attained. To remove the effect of body size from physiological measurements, the allometric equation $\mathrm{Y}=a X^{b}$ was used, where $\mathrm{Y}$ is the physiological parameter, $X$ body size, expressed as dry weight of clam soft tissue, $a$ the intercept of the regression line, representing the value of the physiological measurement/unit of dry weight $(1 \mathrm{~g})$, and $b$ the slope of the regression line. The calculated coefficient was $b=0.68$ for both clearance and respiration rates (Marin, unpublished data). Then physiological measurements were converted to energy equivalents $\left(\mathrm{J} \mathrm{h}^{-1}\right)$ to calculate an energy budget and thus SFG. To obtain the SFG value, expressed by the equation $\mathrm{SFG}=\mathrm{A}-(\mathrm{R}+\mathrm{U})$, the energy absorbed from food A was calculated as $\mathrm{CR}\left(\mathrm{L} \mathrm{h}^{-1}\right) \times \mathrm{POM}\left(\mathrm{mg} \mathrm{L}^{-1}\right) \times$ $23 \mathrm{~J} \times \mathrm{AE}$, where $23 \mathrm{~J}$ is the energy equivalent to $1 \mathrm{mg}$ POM (Widdows, 1978). Respired energy R resulted from RR $\left(\mu \mathrm{mol} \mathrm{O} \mathrm{O}^{-1}\right) \times 0.456 \mathrm{~J}$, where $0.456 \mathrm{~J}$ is the energy equivalent to $1 \mu \mathrm{mol} \mathrm{O}_{2}$ (Gnaiger, 1983). Following Widdows (1993), ammonia excretion (U) was not quantified as this is generally a negligible fraction of the energy budget.

An additional SFG value was calculated using a standardized ration level of $0.4 \mathrm{mg}$ POM and an absorption efficiency of 0.45 (Widdows et al., 1997; Gosling, 2003).

The survival-in-air test was performed on 30 animals from each sampling site, subjected to anoxia by exposure to air at $18^{\circ} \mathrm{C}$ in humidified chambers (Eertman et al., 1993). Survival was assessed daily until $100 \%$ mortality was reached. Animals were considered dead when shell gape occurred, and an external stimulus, such as squeezing of the valves, did not produce any response.

\section{Statistical analysis}

After checking for data normal distribution (Shapiro-Wilk's test) and homogeneity of variances (Bar- 
TABle 2. - Two-way ANOVA results of physiological parameters $(P<0.001)$

\begin{tabular}{lccccc}
\hline Source of variation SS & df & MS & $\mathrm{F}$ & $p$ \\
\hline Clearance rate & & & & & \\
Intercept & 350.425 & 1 & 350.425 & 1433.898 & 0 \\
A (sites) & 8.394 & 2 & 4.197 & 17.174 & $1.5 \mathrm{E}-07$ \\
B (seasons) & 5.784 & 3 & 1.928 & 7.889 & $5.7 \mathrm{E}-05$ \\
A x B & 22.011 & 6 & 3.669 & 15.011 & $7.2 \mathrm{E}-14$ \\
Error & 43.500 & 178 & 0.244 & & \\
& & & & & \\
Respiration rate & & & & & \\
Intercept & 7355.371 & 1 & 7355.371 & 709.193 & 0 \\
A (sites) & 148.425 & 2 & 74.213 & 7.156 & $1.1 \mathrm{E}-03$ \\
B (seasons) & 1038.098 & 3 & 346.033 & 33.364 & $1.1 \mathrm{E}-16$ \\
A x B & 94.007 & 6 & 15.668 & 1.511 & 0.17794 \\
Error & 1628.320 & 157 & 10.371 & & \\
& & & & & \\
SFG & & & & & \\
Intercept & 55746.9 & 1 & 55746.87 & 153.717 & 0 \\
A (sites) & 31643.7 & 2 & 15821.83 & 43.627 & $8.9 \mathrm{E}-16$ \\
B (seasons) & 62125.1 & 3 & 20708.38 & 57.101 & 0 \\
A x B & 146910.2 & 6 & 24485.04 & 67.515 & 0 \\
Error & 56212.2 & 155 & 362.66 & & \\
& & & & & \\
Standardised SFG & & & & & \\
Intercept & 1121.857 & 1 & 1121.857 & 173.099 & 0 \\
A (sites) & 324.199 & 2 & 162.099 & 25.012 & $3.9 \mathrm{E}-10$ \\
B (seasons) & 200.197 & 3 & 66.732 & 10.297 & $3.2 \mathrm{E}-06$ \\
A x B & 244.601 & 6 & 40.767 & 6.290 & $6.1 \mathrm{E}-06$ \\
Error & 1004.555 & 155 & 6.481 & & \\
\hline & & & & & \\
\hline
\end{tabular}

tlett's test), a two-way ANOVA was performed to test the main and interactive effects of season and site on each physiological parameter. Whenever statistically significant differences among samples were detected, pairwise multiple comparisons through LSD test was applied to determine which samples were responsible for the differences. $\mathrm{LT}_{50}$ values (time elapsed to reach $50 \%$ mortality) were calculated according to Kaplan and Meier (1958); the significance of differences between survival curves was tested by the Gehan and Wilcoxon test (Gehan, 1965). Statistical analyses were performed using the STATISTICA 6 software package.

\section{RESULTS}

The results of the two-way ANOVA are shown in Table 2. All physiological parameters were site- and time-dependent. Indeed, both sampling sites and seasons were factors significantly affecting responses $(P<0.001)$. Significant interactions between the two factors (season $\mathrm{x}$ site) were always observed, except for respiration rate.

In September, January and July, the clearance rate was lower in clams from S-F than in those collected at both $\mathrm{C}-\mathrm{F}$ and $\mathrm{C}-\mathrm{NF}$ : significant differences were detected in January and July $(P<0.001)$. Conversely, S-F showed the highest filtering activity in April $(P<0.01)$. When the two Chioggia samples were compared, clams from C-NF generally had higher values, although no significant differences were observed. On a seasonal basis, the highest value was recorded in April at S-F and in July at both C-F and C-NF, and the lowest in January at S-F and in April at both C-F and C-NF (Fig. 2).

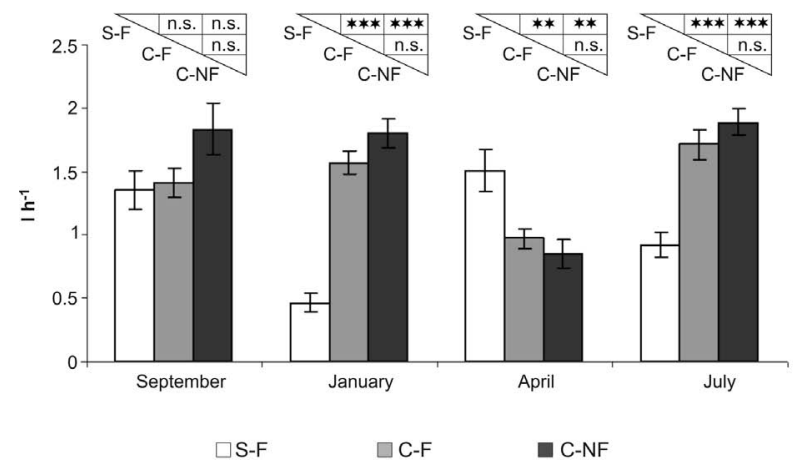

FIG. 2. - Clearance rate in clams collected at S. Angelo (S-F) and Chioggia fishing (C-F) and non-fishing (C-NF) areas. Mean \pm s.e., $* * \mathrm{P}<0.01 ; * * * \mathrm{P}<0.001$.

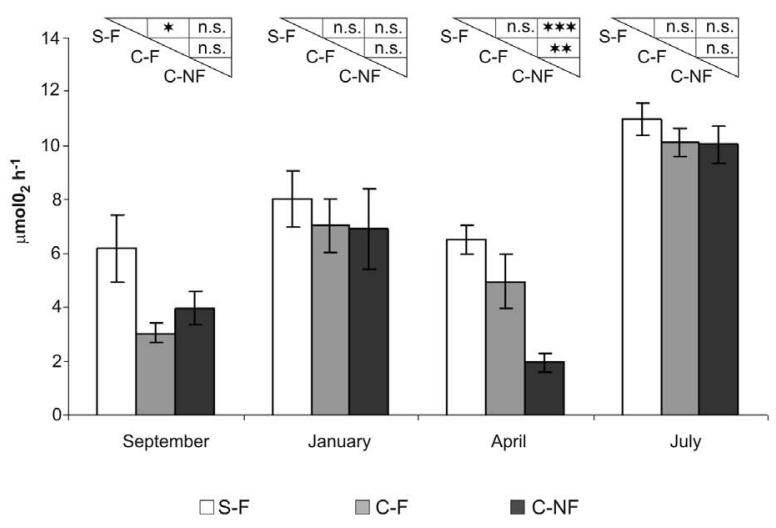

FIG. 3. - Respiration rate in clams collected in S. Angelo (S-F) and Chioggia fishing (C-F) and non-fishing (C-NF) areas. Mean \pm s.e., $* \mathrm{P}<0.05 ; * * \mathrm{P}<0.01 ; * * * \mathrm{P}<0.001$

Respiration rate was always higher in S-F clams, showing significant differences from those from $\mathrm{C}-\mathrm{F}$ in September $(P<0.05)$ and those from $\mathrm{C}-\mathrm{NF}$ in April $(P<0.001)$. Values obtained in $\mathrm{C}-\mathrm{F}$ and $\mathrm{C}-\mathrm{NF}$ samples were generally very similar: $\mathrm{C}-\mathrm{NF}$ oxygen consumption was significantly lower only in April $(P<0.01)$. In July, clams showed significantly increased respiration activity with respect to the other months in all sampled areas (Fig. 3).

The values of POM in seawater and food absorption efficiency (AE) in clams from both S. Angelo and Chioggia are listed in Table 3. The highest POM and AE values were found in July at S. Angelo, and in January and September, respectively, at Chioggia. Moreover,

TABle 3. - Particulate organic matter (POM) content in seawater from S. Angelo (S-F) and Chioggia (C-F / C-NF) and food absorption efficiency (AE) of the various clam samples.

\begin{tabular}{lccccc}
\hline & $\begin{array}{c}\text { Particulate organic matter } \\
\left(\mathrm{mg} \mathrm{1}^{-1}\right)\end{array}$ & \multicolumn{3}{c}{$\begin{array}{c}\text { Absorption efficiency } \\
(\%)\end{array}$} \\
& S-F & C-F / C-NF & S-F & C-F & C-NF \\
\hline September & 0.91 & 0.34 & 11.6 & 49.1 & 47.5 \\
January & 0.39 & 2.60 & 33.7 & 25.4 & 26.6 \\
April & 2.16 & 1.98 & 22.8 & 6.8 & 7.6 \\
July & 9.19 & 0.93 & 73.1 & 30 & 29.4 \\
\hline
\end{tabular}




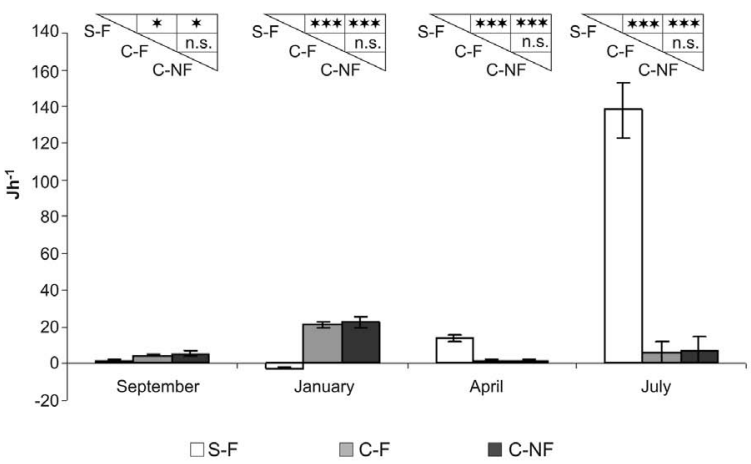

FIG. 4. - Scope for growth in clams collected at S. Angelo (S-F) and Chioggia fishing (C-F) and non-fishing (C-NF) areas. Mean \pm s.e., $* \mathrm{P}<0.05 ; * * * \mathrm{P}<0.001$

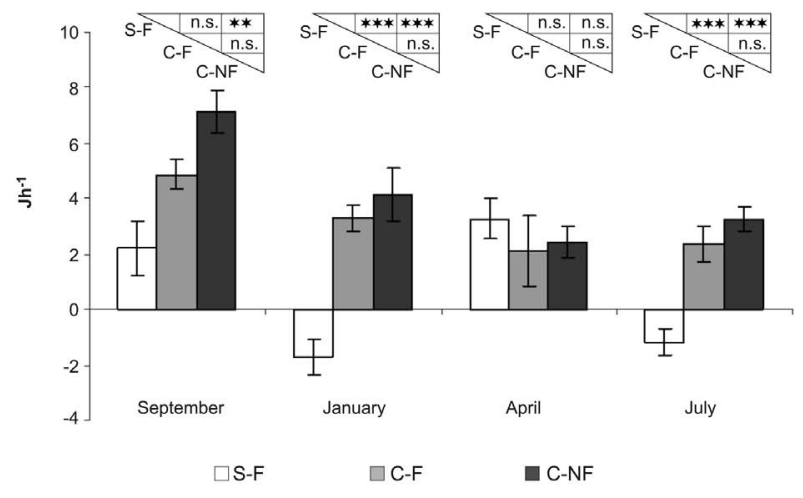

FIG. 5. - Scope for growth calculated using standardized values of $\mathrm{POM}$ and AE in clams collected at S. Angelo (S-F) and Chioggia fishing $(\mathrm{C}-\mathrm{F})$ and non-fishing $(\mathrm{C}-\mathrm{NF})$ areas. Mean \pm s.e., $* * \mathrm{P}<0.01$; $* * * \mathrm{P}<0.001$.

$\mathrm{AE}$ values were always very similar when $\mathrm{C}-\mathrm{F}$ and C-NF samples were compared.

SFG values, calculated with environmental POM and clam AE data, were significantly lower in S-F samples in September $(P<0.05)$ and January $(P<0.001)$ than in those of both C-F and C-NF, whereas the opposite situation was found in April and July $(P<0.001)$. No differences were observed between the SFG of C-F and C-NF clams. On a seasonal basis, SFG peaked in January at Chioggia (21.2 $\mathrm{J} \mathrm{h}^{-1}$ in fishing area, $22.5 \mathrm{~J} \mathrm{~h}^{-1}$ in non-fishing area) and in July in the S-F sample (138.1 $\left.\mathrm{J} \mathrm{h}^{-1}\right)$; the only negative value was recorded in January in S-F clams (Fig. 4).

SFG, based on standardized POM and AE values, generally showed the lowest values in the S-F samples: significant differences were detected in September in comparison with C-NF clams $(P<0.01)$, and in January and July in comparison with both $\mathrm{C}-\mathrm{F}$ and $\mathrm{C}-\mathrm{NF}$ clams $(P<0.001)$ (Fig. 5).

In September, the survival-in-air test showed a significantly higher $\mathrm{LT}_{50}$ value $(P<0.001)$ in $\mathrm{S}-\mathrm{F}$ clams (6.5 days) than in C-F and C-NF clams (5 days in both areas). In January, a significantly lower resistance to aerial exposure was found in clams from C-F (4.5 days; $P<0.001)$. No differences were detected in survival curves in April and July (Table 4).
TABLE 4. - $\mathrm{LT}_{50}$ values (in days) and statistical comparison of survival curves in $R$. philippinarum seasonally collected at $\mathrm{S}$. Angelo $(\mathrm{S}-\mathrm{F})$ and Chioggia fishing $(\mathrm{C}-\mathrm{F})$ and non-fishing $(\mathrm{C}-\mathrm{NF})$ areas. $\mathrm{N}=30$. Wilcoxon and Gehan test: n.s. $P>0.05$, *** $P<0.001$.

\begin{tabular}{lcccccc}
\hline & S-F & C-F & C-NF & $\begin{array}{c}\text { S-F vs } \\
\text { C-F }\end{array}$ & $\begin{array}{c}\text { S-F-vs } \\
\text { C-NF }\end{array}$ & $\begin{array}{c}\text { C-F vs } \\
\text { C-NF }\end{array}$ \\
\hline September & 6.5 & 5 & 5 & $* * *$ & $* * *$ & n.s. \\
January & 5 & 4.5 & 6 & $* * *$ & n.s. & $* * *$ \\
April & 6.5 & 7 & 7 & n.s. & n.s. & n.s. \\
July & 6 & 6 & 6 & n.s. & n.s. & n.s. \\
\hline
\end{tabular}

\section{DISCUSSION}

Some physiological responses (clearance rate, respiration rate, SFG and survival in air) generally used to determine possible chronic stress conditions undergone by marine bivalves were used in the present study to evaluate the potential long-term effects of fishing on $R$. philippinarum populations from the Lagoon of Venice. Sampling surveys were carried out seasonally at two sites subjected to different fishing efforts: a free fishing area at S. Angelo (central basin) and an area licensed for clam farming at Chioggia (southern basin), where a control sub-area was established. Two SFG values were also evaluated: one was calculated with POM and $\mathrm{AE}$ values, in order to highlight environmental differences between S. Angelo and Chioggia, and the other with standardized POM $(0.4 \mathrm{mg})$ and AE $(0.45)$ values, to better reveal the effects of stress due to fishing, when other natural potential stressors were held constant (Widdows et al., 1997).

$R$. philippinarum from S. Angelo generally showed reduced filtering activity and higher oxygen consumption, thus revealing overall worsening in clam wellbeing in comparison with individuals from both areas of Chioggia. This condition, resulting in lower-and sometimes negative-standardized SFG values, may be explained by both environmental differences at the sampling sites and different types of fishing management. S. Angelo is located in the central basin of the Lagoon of Venice, the most severely influenced by anthropogenic activities, considering its nearness to both the industrial and port area of Marghera and the city of Venice. Despite this, the whole area is particularly suitable for recruitment and growth of $R$. philippinarum (Pranovi et al., 2003), due to the prevailing sediment features and the thermal influence of wastewater from the Fusina power plant, which enhances productivity (Socal et al., 1999). Although fishing is not allowed in the shallow waters bordering the industrial area, because it is highly polluted by nutrients, hydrocarbons and heavy metals (Frignani et al., 2005; Secco et al., 2005; Bernardello et al., 2006), its high productivity attracts a great number of illegal clam fishermen. The worse conditions of the S. Angelo clams, highlighted by filtering activity and oxygen consumption, is in accordance with the results reported in a previous study by Matozzo et al. (2003) on the functional responses of haemocytes in $R$. philippinarum collected from the 
same sites. These authors showed that clams from $\mathrm{S}$. Angelo generally exhibited a reduced immune response (i.e. haemocyte number and phagocytic activity) in comparison with individuals from Chioggia.

The peculiar environmental features of the two lagoon areas were better highlighted by SFG calculated using POM values in seawater and AE in clams. The high SFG values at S. Angelo in April and July and at Chioggia in January were mainly due to greater and/ or qualitatively different food availability, rather than to variations in clam physiological performance. In particular, the increase in suspended organic matter in seawater was associated with phytoplankton blooms, except for S-F in April, as shown by chlorophyll $a$ values (see, for details, Marin et al., 2003). Interestingly, the highest SFG values in S-F clams in April and July were also associated with the highest AE values.

Other conclusions on the effects of fishing on clams can be reached by comparing samples from Chioggia (fishing and non-fishing areas). Physiological parameters rarely exhibited statistically significant differences between clams from the two areas, although higher clearance rates and standardized SFG were often observed in organisms from the non-fishing area, suggesting a better state of health. Interestingly, similar results were obtained in the study of Marin et al.(2003) by evaluating gross biochemical composition and condition index in clams collected from the same sites. Particularly in the period February-May, total carbohydrates, glycogen and condition index showed the highest values in clams from the Chioggia non-fishing area. The relationship between energy availability measured at both cellular (through biochemical composition) and organism (through SFG) levels is highlighted, confirming the results obtained in the freshwater mussel Dreissena polymorpha by Smolders et al. (2004).

It should be noted that the fishing area inside a clam farm is characterized by continuous rearrangements, that is, cultivated clams are often graded, sorted and transported from one part to the other within the clam farm, mainly by hydraulic dredging. All these operations, and the constant introduction of specimens from other lagoon and extra-lagoon sites, probably cause increased stress conditions and, consequently, an increase in the energy required for metabolic processes.

The survival-in-air test did not give clear responses in evaluating the effects of fishing on clams, perhaps because they were mostly influenced by exogenous factors such as seawater temperature, as well as by endogenous factors such as reproductive stage and availability of body reserves (Eertman et al., 1993). In January the survival was significantly lower in clams from $\mathrm{C}-\mathrm{F}$ than in specimens from both $\mathrm{C}-\mathrm{NF}$ and $\mathrm{S}-\mathrm{F}$, whereas in April and July no significant differences were recorded among samples. Matching these results, previous field studies showed better responsiveness and consequently increased discriminating capability of the survival-in-air test in winter, when body glycogen content is lowest (Eertman et al., 1993; Marin et al., 2001). Indeed, in anaerobic conditions, glycogen is used as the only substrate for ATP generation (Zandee et al., 1986). The strong correlation between this body reserve and the anaerobic pathway was statistically confirmed, when the seasonal variations in $\mathrm{LT}_{50}$ values reported here were compared with those of total carbohydrates and glycogen contents (positive Spearman correlation coefficient: $P<0.01$ ) determined by Marin et al. (2003). Although respiration rate peaked in July at all sampling sites, as a consequence of increased water temperature, filtering activity and SFG did not show marked seasonal trends, the latter rarely exhibiting negative values. These results suggest that $R$. philippinarum is highly tolerant to environmental changes. It should also be noted that, as observed by Widdows et al. (1997) in Mytilus galloprovincialis, food supply in the Lagoon of Venice is so abundant everywhere throughout the year that it counteracts the detrimental effects of both natural and anthropogenic stressors on clam physiological responses. Nevertheless, when the SFG calculated by standardized POM and AE values was considered, in July negative SFG values were observed, highlighting the negative effect of high water temperature on physiological rates, as already observed in other clam species such as $R$. decussatus and Chamelea gallina (Sobral and Widdows, 1997a,b; Moschino and Marin, 2006).

\section{CONCLUSIONS}

The wide distribution and abundance of the Manila clam $R$. philippinarum in the whole Lagoon of Venice has been attributed to its great tolerance to environmental changes, and its resistance to parasites and pollution. In addition, this species may take nutritional advantages from exploitation, due to the re-suspension of organic matter, mostly produced by the frequent action of fishing gear on the bottom. This apparent beneficial effect of dredging results in population enhancement, clams being more abundant in fishing grounds than elsewhere. In particular, at S. Angelo high food availability may allow clams to cope with overall detrimental effects due to increased pollution levels, which are instead highlighted by specific responses such as clearance and respiration. Our results on the physiological performance of $R$. philippinarum confirm the great tolerance of this species to changing environmental conditions. The results obtained for clams from the same lagoon area at Chioggia, but subjected to different fishing efforts, seems to corroborate the above statements. Indeed, on the whole, although fishing causes a slight increase in stress conditions, suggesting worsening of the state of health of clams, greater differences would have been expected between clams from fishing and non-fishing areas.

\section{ACKNOWLEDGEMENTS}

This study was carried out with funding from the European Commission DGXIV (Studies 99/062): 
"Assessing the impact of bivalve fisheries on the benthic ecosystems of the Ria Formosa lagoon (Portugal), Venice lagoon (Italy), Aegean Sea (Kavala-Greece) and on the juvenile flatfish in the South coast of Portugal (IMPACTO)".

\section{REFERENCES}

Apitz, S.E., A. Barbanti, A.G. Bernstein, M. Bocci, E. Delaney and L. Montobbio. - 2007. The assessment of sediment screening risk in Venice lagoon and other coastal areas using international sediment quality guidelines. J. Soils Sed., 7: 326-341.

Bellucci, L.G., M. Frignani, D. Paolucci and M. Ravanelli. - 2002. Distribution of heavy metals in sediments of the Venice Lagoon: the role of the industrial area. Sci. Total Environ., 295: 35-49.

Bernardello, M., T. Secco, F. Pellizzato, M. Chinellato, A. Sfriso and B. Pavoni. - 2006. The changing of contamination in the Lagoon of Venice. Part 2: Heavy metals. Chemosphere, 64 1334-1345.

Chicharo, M.A. and L. Chicharo. - 2008. RNA:DNA ratio and other nucleic acid derived indices in marine ecology. Int. J. Mol. Sci. 9. $1453-1471$

Chícharo, M.A., A. Amaral, S. Condinho, F. Alves, J. Regala, M. Gaspar and L. Chícharo. - 2003. Adenylic-derived indices and reburying time as indicators of the effects of dredging induced stress on the clam Spisula solida. Mar. Biol., 142: 1113-1117

Conover, R.J. - 1966 Assimilation of organic matter by zooplankton. Limnol. Oceanogr. 11: 338-354.

Da Ros, L., N. Nesto, C. Nasci, V. Moschino, D. Pampanin and M.G. Marin. - 2003. Biochemical and behavioural effects of hydraulic dredging on the target species Chamelea gallina. Fish. Res., 64: 71-78.

Eertman, R.H.M., A.J. Wagenvoort, H. Hummel and A.C. Smaal. 1993. "Survival in air" of the blue mussel Mytilus edulis L. as a sensitive response to pollution-induced environmental stress. $J$. Exp. Mar. Biol. Ecol., 170: 179-195.

Frignani, M., L.G. Bellucci, M. Favotto and S. Albertazzi. - 2005. Pollution historical trends as recorded by sediments in selected sites of the Venice Lagoon. Environ. Int., 31: 1011-1022.

Gaspar, M.B. and L. Chicharo. -2007 . Modifying dredges to reduce by-catch and impacts on the benthos. In: S.J. Kennelly (ed.), Bycatch reduction in the world's fisheries, pp. 95-140. Springer.

Gaspar, M.B., F. Leitão, M.N. Santos, M. Sobral, L. Chícharo, A Chícharo and C.C. Monteiro. - 2003. Size selectivity of the Spisula solida dredge in relation to tooth spacing and mesh size. Fish. Res., 60: 561-568.

Gaspar, M.B., S. Carvalho, R. Constantino, J. Tata-Regala, J. Cúrdia and C.C. Monteiro. - 2009. Can we infer dredge fishing effort based on macrobenthic community structure? ICES $J$. Mar. Sci., 66: 2121-2132.

Gehan, E.A. - 1965. A generalized Wilcoxon test for comparing arbitrarily singly censored samples. Biometrika, 52: 203-223.

Gnaiger, E. - 1983. Heat dissipation and energetic efficiency in animal anoxibiosis: economy contra power. J. Exp. Zool., 228: 471-490.

Gosling, E. - 2003. Bivalve molluscs: Biology, Ecology and Culture. Fishing News Books, Blackwell Publishing, Oxford.

Hauton, C., J.M. Hall-Spencer and P.G. Moore. - 2003. An experimental study of the ecological impacts of hydraulic bivalve dredging on maerl. ICES J. Mar. Sci., 60: 381-392.

Kaplan, E.L. and P. Meier. - 1958. Nonparametric estimation from incomplete observations. J. Am. Stat. Assoc., 53: 457-481

Kraan, C., T. Piersma, A. Dekinga, A. Koolhaas and J. van der Meer. - 2007. Dredging for edible cockles (Cerastoderma edule) on intertidal flats: short-term consequences of fisher patch-choice decisions for target and non-target benthic fauna. ICES J. Mar. Sci., 64: 1735-1742.

Labarta, U., M.J. Fernandez-Reiriz and J.M.F. Babarro. - 1997. Differences in physiological energetics between intertidal and raft cultivated mussels Mytilus galloprovincialis. Mar. Ecol. Prog. Ser., 152: 167-173.

Leitão, F., M.B. Gaspar, M.N. Santos and C.C. Monteiro. - 2009. A comparison of bycatch and discard mortality in three types of dredge used in the Portuguese Spisula solida (solid surf clam) fishery. Aquat. Living Resour., 22: 1-10.

Marin, M.G., N. Nesto and L. Da Ros. - 2001. Evaluation of biological stress indices in Tapes philippinarum from the Lagoon of Venice, through monitoring of natural populations and transplantation experiments. In: Faranda, F.M., L. Guglielmo and G. Spezie (eds.), Structures and Processes in the Mediterranean Ecosystem, pp. 91-94. Springer-Verlag, Italia, Milan.

Marin, M.G., V. Moschino, M. Deppieri and L. Lucchetta. - 2003. Variations in gross biochemical composition, energy value and condition index of Tapes philippinarum from the Lagoon of Venice. Aquaculture, 219: 859-871.

Marin, M.G., V. Moschino, F. Meneghetti and L. Da Ros. - 2005. Effects of mechanical stress in under-sized clams, Tapes philippinarum: a laboratory approach. Aquacult. Int., 13: 75-88.

Matozzo, V., L. Da Ros, L. Ballarin, F. Meneghetti and M.G. Marin. -2003 . Functional responses of haemocytes in the clam Tapes philippinarum from the Lagoon of Venice: fishing impact and seasonal variations. Can. J. Fish. Aquat. Sci., 60: 949-958.

Morello, E.B., C. Froglia, R.J.A. Atkinson and P.G. Moore. -2005. Hydraulic dredge discards of the clam (Chamelea gallina) fishery in the western Adriatic Sea, Italy. Fish. Res. 76: 430-444.

Moschino, V. and M.G. Marin. - 2006. Seasonal changes in physiological responses and evaluation of "well-being" in the Venus clam Chamelea gallina from the Northern Adriatic Sea. Comp. Biochem. Phys., 145: 433-440.

Moschino, V., L.M.Z. Chicharo and M.G. Marin. - 2008. Effects of hydraulic dredging on the physiological responses of the target species Chamelea gallina (Mollusca: Bivalvia): laboratory experiments and field surveys. Sci. Mar., 72: 493-501.

Pellizzato, M. and L. Da Ros. - 2005. Clam farming quality as a management tool: a proposal based on recent studies in Northern Adriatic lagoons. Aquacult. Int., 13: 57-66.

Pranovi, F. and O. Giovanardi. - 1994. The impact of hydraulic dredging for short-necked clams, Tapes spp., on an infaunal community in the Lagoon of Venice. Sci. Mar., 58: 345-353.

Pranovi, F., O. Giovanardi and G. Franceschini. - 1998. Recolonization dynamics in areas disturbed by bottom fishing gears. Hydrobiologia, 375/376: 125-135.

Pranovi, F., S. Raicevich, G. Franceschini, P. Torricelli and O. Giovanardi. - 2001. Discard analysis and damage to non-target species in the "rapido" trawl fishery. Mar. Biol., 139: 863-875.

Pranovi, F., S. Libralato, S. Raicevich, A. Granzotto, R. Pastres and O. Giovanardi. - 2003. Mechanical clam dredging in Venice lagoon: ecosystem effects evaluated with a trophic mass-balance model. Mar. Biol., 143: 393-403.

Secco, T., F. Pellizzato, M. Chinellato, A. Sfriso and B. Pavoni. 2005. The changing of contamination in the Lagoon of Venice. Part 1: organic pollutants. Chemosphere, 58: 276-290.

Smaal, A.C. and J. Widdows. - 1994. The Scope for Growth in bivalves as an integrated response parameter in biological monitoring. In: K.J.M. Kramer (ed.), Biomonitoring of Coastal waters and Estuaries, pp. 247-267. CRC Press, Boca Raton.

Smolders, R., L. Bervoets, W. De Coen and R. Blust - 2004. Cellular energy allocation in zebra mussels exposed along a pollution gradient: linking cellular effects to higher levels of biological organization. Environ. Pollut., 129: 99-112.

Sobral, P. and J. Widdows. - 1997a. The influence of hypoxia and anoxia on the physiological responses of the clam Ruditapes decussatus L. from Southern Portugal. Mar. Biol., 127: 455-461.

Sobral, P. and J. Widdows. - 1997b. Effects of elevated temperatures on the scope for growth and resistance to air exposure of the clam Ruditapes decussatus (L.) from southern Portugal. Sci. Mar., 61: 163-171.

Socal, G., F. Bianchi and L. Alberighi. - 1999. Effects of thermal pollution and nutrient discharges on a spring phytoplankton bloom in the industrial area of the Lagoon of Venice. Vie Milieu, 49: 19-31.

Wepener, V., L. Bervoets, V. Mubiana and R. Blust. - 2008. Metal exposure and biological responses in resident and transplanted blue mussels (Mytilus edulis) from the Scheldt estuary. Mar. Pollut. Bull., 57: 624-631.

Widdows, J. - 1978. Combined effects of body size, food concentration, and season on the physiology of Mytilus edulis. J. Mar. Biol. Assoc. U.K. 58: 109-124.

Widdows J. - 1985. Physiological measurements and physiological procedures. In: Bayne, B.L., D.A. Brown, , K. Burns, D.R. Dixon, A. Ivanovici, D.R. Livingstone, D.M. Lowe, M.N. Moore, 
$110 \cdot \mathrm{V}$. MOSCHINO et al.

A.R.D. Stebbing and J. Widdows (eds.) The Effects of Stress and Pollution on Marine Animals, pp. 3-45. Preager Publishers, New York.

Widdows, J. - 1993. Marine and estuarine invertebrate toxicity tests. In: Calow, P. (Ed.), Handbook of Ecotoxicology, vol. 1, pp. 145-166. Blackwell Scientific Publishers, London.

Widdows, J., C. Nasci and V.U. Fossato. - 1997. Effects of pollution on the scope for growth of mussels (Mytilus galloprovincialis) from the Venice lagoon, Italy. Mar. Environ. Res., 43: 69-79.
Zandee, D.I., D.A. Holwerda, J.H. Kluytmans and A. de Zwaan. - 1986. Metabolic adaptations to environmental anoxia in the intertidal bivalve mollusk Mytilus edulis L. Neth. J. Zool., 36: 322-343.

Scient. ed.: M. Gaspar.

Received November 17, 2009. Accepted May 28, 2010.

Published online December 23, 2010. 